\title{
ASSESSMENT OF THYROID CANCER INCIDENCE IN KAZAKHSTAN
}

Moldir YERLANKYZY1,2, https://orcid.org/0000-0001-8266-2945,

Sauirbay B SAKHANOV ${ }^{1,2}$, https://orcid.org/0000-0002-5496-5313,

Dulat K TUREBAYEV ${ }^{1}$, https://orcid.org/0000-0003-1557-3496,

Dariyana M KULMIRZAYEVA ${ }^{3,2}$, https://orcid.org/0000-0001-8174-0171,

Saltanat N URAZOVA ${ }^{1}$, https://orcid.org//0000-0002-2331-1261,

Akmaral K AMANSHAYEVA ${ }^{2}$, https://orcid.org/0000-0003-0002-5884,

Zarina A BILYALOVA², https://orcid.org/0000-0002-0066-235x,

Nurbek S IGISSINOV ${ }^{1,2,4}$, https://orcid.org/0000-0002-2517-6315

${ }^{1}$ Astana Medical University, Nur-Sultan, Republic of Kazakhstan,

${ }^{2}$ Central Asian Cancer Institute, Nur-Sultan, Republic of Kazakhstan,

${ }^{3}$ National Center of Neurosurgery, Nur-Sultan, Republic of Kazakhstan,

${ }^{4}$ Eurasian Institute for Cancer Research, Bishkek, Kyrgyz Republic

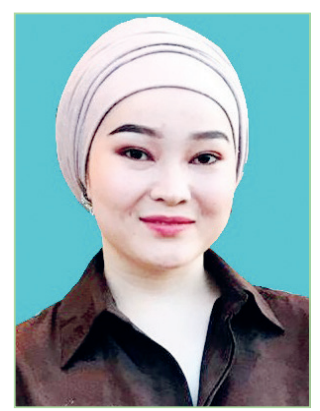

Yerlankyzy M

Thyroid cancer (TC) is the most wide spread malignant tumor of the endocrine glands. According to the International Agency for Research on Cancer, more than 586,200 new cases of TC were registered in the world in 2020. However spatial arrangement of this disease indicates a different distribution of this pathology all over the world.

The aim to assess the peculiarities of the incidence of TC in Kazakhstan.

Materials and methods. The study was retrospective - the study period was 10 years (20092018). The material for the study was data of new cases of TC. In the research were used descriptive and analytical methods of oncoepidemiology.

Results and discussion. We found out that the average age of patients with TC in women (51.8 \pm 0.2 years) were less than in men ( $53.2 \pm 0.5$ years). The crude rate and standardized incidence rates in women $(5.4 \pm 0.4 \% 000$ and $5.1 \pm 0.37 \%$ ooo, respectively) were higher than in men $(0.9 \pm 0.1 \%$ oo and $1.1 \pm 0.1 \%$ ooo, respectively). Age-related indicators of the incidence of TC were characterized by a peak in $60-69$ years $-4.21 \pm 0.20 \%$ oo in men and $15.37 \pm 1.21 \%$ oo in women. Trends in morbidity tended to increase in both women $(\mathrm{Tg}=+7.8 \%)$ and men $(\mathrm{Tg}=+5.0 \%)$.

Conclusion: Age and gender features of TC incidence were established in the whole country. The obtained data are recommended for use in planning anti-cancer activities.

Key words: thyroid cancer, incidence, Kazakhstan.

For reference: Yerlankyzy M, Sakhanov SB, Turebayev DK, Kulmirzaeva DM, Urazova SN, Amanshayeva AK, Bilyalova ZA, Igissinov NS. Assessment of thyroid cancer incidence in Kazakhstan. Meditsina (Almaty) = Medicine (Almaty). 2020;11-12(221-222): 2-7. DOI: 10.31082/1728-452X-2020221-222 -11-12-2-7

\section{Т ¥ Ж Ы Р Ы $\mathrm{M}$}

\section{ҚАЗАҚСТАНДАҒЫ ҚАЛҚАНША БЕЗІ ҚАТЕРЛІ ІСІГІН БАҒАЛАУ}

Мөлдір ЕРЛАНҚЫЗЫ1,2, https://orcid.org/0000-0001-8266-2945, Сәуірбай Б. САХАНОВ ${ }^{1,2}$, https://orcid.org/0000-0002-5496-5313, Дулат К. ТӨРЕБАЕВ1, https://orcid.org/0000-0003-1557-3496, Дарияна М. КҮЛМЫРРЗАЕВА ${ }^{3,2}$, https://orcid.org/0000-0001-8174-0171, Салтанат Н. ОРАЗОВА', https://orcid.org//0000-0002-2331-1261, Ақмарал Қ. АМАНШАЕВА ${ }^{2}$, https://orcid.org/0000-0003-0002-5884, Зарина А. БИЛЯЛОВА ${ }^{2}$, https://orcid.org/0000-0002-0066-235X, Нұрбек С. ИГІСІНОВ ${ }^{1,2,4}$, https://orcid.org/0000-0002-2517-6315

Conts: Moldir Yerlankyzy, ern of Astana Medical University, General Medical Practice faculty, Member of Public Association "Central Asian Cance Institute", Nur-Sultan c., e-mail: yerlankyzy.moldir@gmail.com

Контакты: Ерланкызы Молдир, интерн 7 курса НАO

"Медицинский университет Астана", факультет общей врачебной практики, член OO "Central Asian Cancer Institute", г. Нур-Султан, e-mail: yerlankyzy. moldir@gmail.com

Поступила: 20.12.2020 ана медицина университеті» ҚеАҚ, Нұр-Сұлтан қ., Қазақстан Республикасы, ${ }^{2}$ Central Asian Cancer Institute, Нұр-Сұлтан қ., Қазақстан Республикасы,

${ }^{3}$ «лттық нейрохирургия орталығы» АҚ, Нұр-Сұлтан қ., Қазақстан Республикасы, ${ }^{4}$ Қатерлі ісікті зерттеу Еуразиялық институты, Бішкек қ., Қырғыз Республикасы

Қалқанша безі қатерлі ісігі эндокриндік бездердің ішінде ең көп кездесетін қатерлі ісік. Обырды зерттеу жөніндегі халықаралық агенттіктің мәліметтері бойынша, 2020 жылы әлемде 586 200-ден астам жаңа қалқанша безі қатерлі ісігі ауруы тіркелді және әлемде әр түрлі көрсеткіштерге ие болды.

Зерттеудің мақсаты. Қазақстанда қалқанша безі қатерлі ісігі ауруының ерекшеліктерін бағалау.

Материал және әдістері. Зерттеу ретроспективті - зерттелетін кезең 10 жылды құрады

Reviewer: Soodonbekov Enver Tentievich, Candidate of Medical Sciences, Head of the Department of Epidemiology and Prevention of Malignant Neoplasms, National Center of Oncology and Hematology of the Ministry of Health of the Kyrgyz Republic, Bishkek, e-mail: soodonbekov65@mail.ru 
(2009-2018 жж.). Зерттеуге арналған материал жаңа қалқанша безі қатерлі ісігі жағдайлары туралы мәліметтер болды. Онкоэпидемиологияның сипаттамалық және аналитикалық әдістері қолданылды.

Нәтижелері және талқылауы. Әйелдерде қалқанша безі қатерлі ісігі бар науқастардың ор-

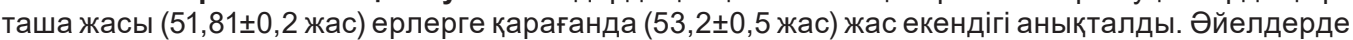

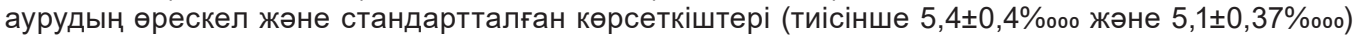

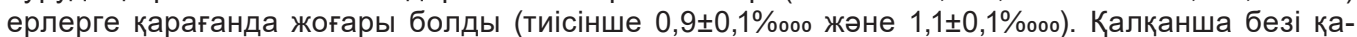
терлі ісігімен сырқаттанушылықтың жас көрсеткіштері 60-69 жас аралығындағы шыңға жетті

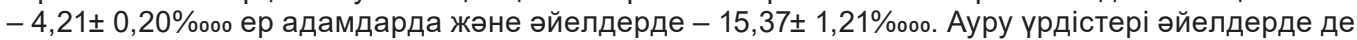
( $\mathrm{T \ominus}=+7,8 \%)$ және ерлерде де $\left(\mathrm{T}_{\theta}=+5,0 \%\right)$ өсу үрдісіне ие болды.

қорытынды. Жалпы республика бойынша қалқанша безі қатерлі ісігімен сырқаттанушылықтың жас-жыныстық ерекшеліктері анықталды. Алынған мәліметтерді қатерлі ісікке қарсы шараларды жоспарлау кезінде қолдану ұсынылады.

Негізгі сөздер: қалқанша безінің қатерлі ісігі, аурушаңдық, Қазақстан.

\section{P E 3 Ю M E}

ОЦЕНКА ЗАБОЛЕВАЕМОСТИ РАКОМ ЩИТОВИДНОЙ ЖЕЛЕЗЫ В КАЗАХСТАНЕ
Мөлдір ЕРЛАНҚЫЗЫ1,2, https://orcid.org/0000-0001-8266-2945,
Сәуірбай Б. САХАНОВ ${ }^{1,2}$, https://orcid.org/0000-0002-5496-5313,
Дулат К. ТУРЕБАЕВ ${ }^{1}$, https://orcid.org/0000-0003-1557-3496,
Дарияна М. КУЛЬМИРЗАЕВА ${ }^{3,2}$, https://orcid.org/0000-0001-8174-0171,
Салтанат Н. УРАЗОВА ${ }^{1}$, https://orcid.org//0000-0002-2331-1261,
Акмарал К. АМАНШАЕВА ${ }^{2}$, https://orcid.org/0000-0003-0002-5884,
Зарина А. БИЛЯЛОВА ${ }^{2}$, https://orcid.org/0000-0002-0066-235X,
Нурбек С. ИГИСИнОВ ${ }^{1,2,4}$, https://orcid.org/0000-0002-2517-6315
${ }^{1} \mathrm{HAO}$ «Медицинский университет Астана», г. Нур-Султан, Республика Казахстан, ${ }^{2}$ Central Asian Cancer Institute, z. Нур-Султан, Республика Казахстан,
${ }^{3}$ АО «Национальный центр нейрохирургии», е. Нур-Султан, Республика Казахстан,
${ }^{4}$ Евразийский институт изучения рака, г. Бишкек, Кырәызская Республика

РщЖ наиболее часто встречающаяся злокачественная опухоль эндокринных желез. По данным Международного агентства по изучению рака в 2020 году в мире было зарегистрировано более 586200 новых случаев РЩЖ, при этом заболеваемость имела различную вариабельность в мире.

Цель исследования. Оценить особенности заболеваемости РЩЖ в Казахстане.

Материал и методы. Исследование ретроспективное - изучаемый период составил 10 лет (2009-2018 гг.). Материалом для исследования послужили данные о новых случаях РЩЖ. Использовались дескриптивные и аналитические методы онкоэпидемиологии.

Результаты и обсуждение. Установлено, что средний возраст больных РЩЖ у женщин

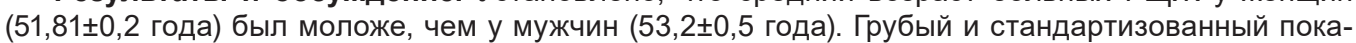
затели заболеваемости у женщин $(5,4 \pm 0,4 \%$ ооо и $5,1 \pm 0,37 \%$ ооо соответственно) были выше, чем у мужчин $(0,9 \pm 0,1 \%$ ооо и $1,1 \pm 0,1 \%$ ооо соответственно). Возрастные показатели заболеваемости

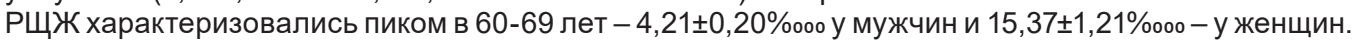
Тренды заболеваемости имели тенденцию к росту и у женщин $\left(\mathrm{T}_{\text {пр }}=+7,8 \%\right)$ и у мужчин $\left(\mathrm{T}_{\text {пр }}=+5,0 \%\right)$.

Выводы. Установлены возрастно-половые особенности заболеваемости РЩЖ в целом по республике. Полученные данные рекомендуются использовать при планировании противораковых мероприятий.

Ключевые слова: рак щитовидной железы, заболеваемость, Казахстан.

Для цитирования: Ерланқызы М., Саханов С.Б., Торебаев Д.К., Кульмурзаева Д.М., Уразова С.Н., Аманшаева А.К., Билялова З.К., Игисинов Н.С. Оценка заболеваемости раком щитовидной железы в Казахстане. Медицина (Алматы). 2020;11-12(221-222): 2-7. DOI: 10.31082/1728452X-2020-221-222-11-12-2-7

C ancer of thyroid is the most widespread malignant tumor of the endocrine glands. According to the International Agency for Research on Cancer, in 2020 were registered more than 586,200 new cases of thyroid cancer in the world. However spatial arrangement of this disease indicates a different distribution of this pathology all over the world $[1,2,3]$. Thus, the highest standardized (world standard) indicators were registered in Korea $(26.6 \% 000)$, Cyprus (19.3\%ooo), and Canada (17.4\%ooo) (figure 1).
Carcinogenic effects of the TC classified as endogenous or exogenous, which includes physical, chemical, and biological factors. In studies of oncological pathology of the TC, the effect of ionizing radiation on the body is shown as one of the leading etiological factors $[4,5,6,7]$. In addition, the role of dose and type of exposure (single and multiple exposure), gender and age of the subject, features of angiogenesis, autoimmune reaction, and variations in the intake of iodine to the thyroid were observed. It was revealed that one of the main 


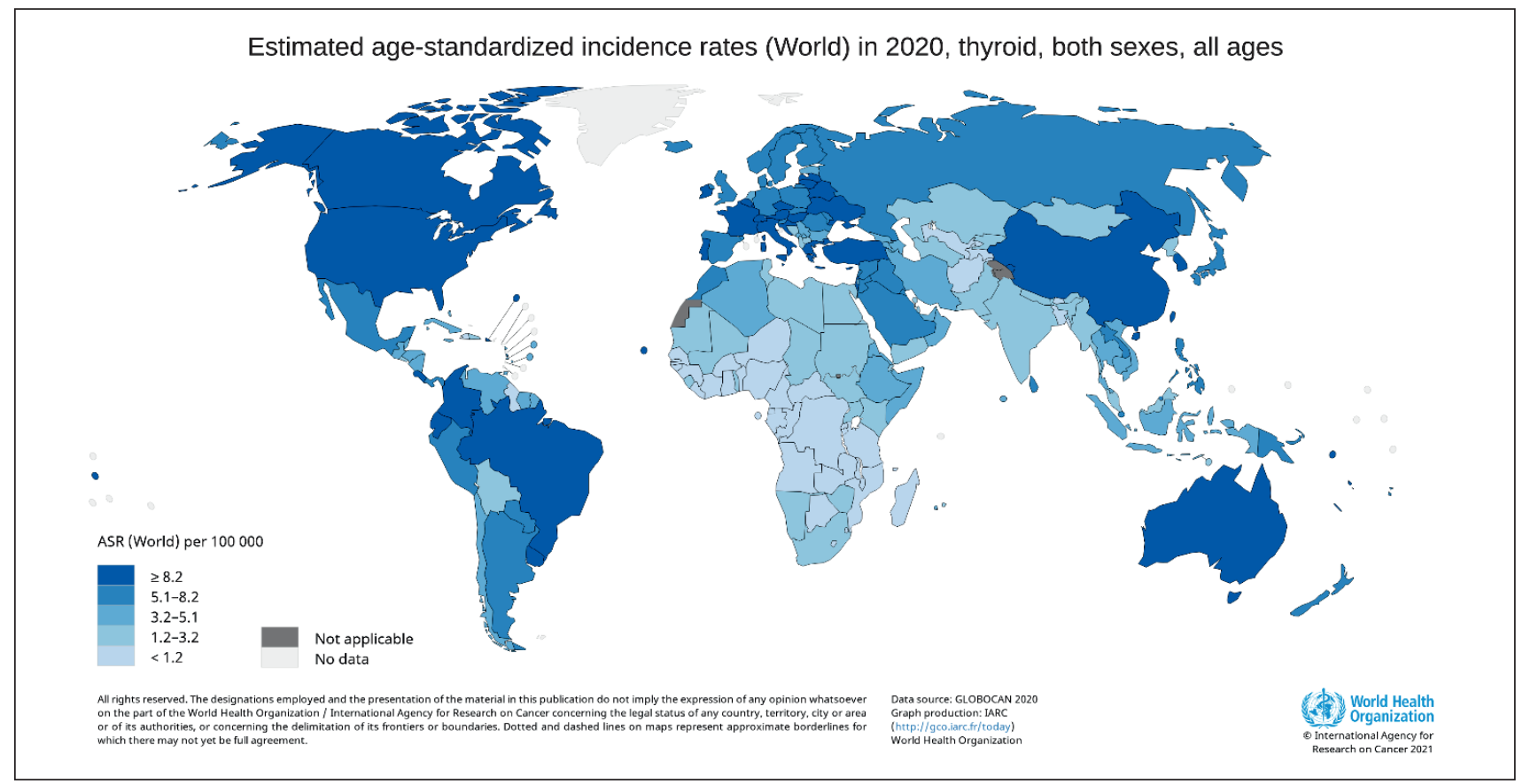

Figure 1 - Cartogram of the standardized indicator of TC in the world [1]

factors contributing to the transformation of normal thyroid cells into tumor cells is the stimulation of the proliferation of thyrocytes under the influence of hormonal influences, growth factors, and iodine deficiency $[8,9]$.

The aim to assess the peculiarities of the incidence of TC in Kazakhstan.

\section{MATERIAL AND METHODS}

The study is retrospective - the research period was 10 years (2009-2018). The material for the study was data of new cases of TC from accounting and reporting documents (form 7,35 ) of oncological institutions of the republic. The paper based on data from the Bureau of National Statistics of the Agency for Strategic Planning and Reforms of the Republic of Kazakhstan about population size considering factors such as gender and age. In analyze of TC epidemiology descriptive and analytical methods were used (10).

Extensive, crude rate, age-specific incidence rate and age-standardized incidence rate are calculated and determined according to the generally accepted methodology used in bio- medical statistics $[11,12,13]$. Age-standardized rate (ASR) are calculated in a direct way, using the world population standard [14] with recommendations for its calculation [15]. The disease rates are calculated per 100,000 of the corresponding population. The dynamics of the indicators were studied over 10 years, and the trends were determined by the least squares method. Geometric mean was used to calculate the average annual growth/loss rate of the dynamics. The average age of the patients, the average values $(\mathrm{M}, \mathrm{P})$, the mean error $(\mathrm{m})$ and the average annual growth/loss rate of the equalized indicators ( Tg/d, \%), 95\% confidence intervals (95\% CI), and the cumulative risk were calculated.

\section{RESULTS AND DISCUSSION}

In 2009-2018, 5,559 cases of TC were detected for the first time, including 4,773 (85.9\%) women and $786(14.1 \%)$ men. Peak of disease was 55-59 years in both men (15.3\%) and women (13.3\%) (table 1).

The average age of patients with TC in women during the study period was $51.8 \pm 0.2$ years $(95 \% \mathrm{CI}=51.5-52.2$ years),

Table 1 - TC by age and gender in Kazakhstan, 2009-2018

\begin{tabular}{|c|c|c|c|c|c|c|}
\hline \multirow{2}{*}{ Age groups, years } & \multicolumn{3}{|c|}{ Both sexes } & \multicolumn{4}{c|}{ of these: } \\
\cline { 2 - 8 } & Number & $\%$ & Number & $\%$ & \multicolumn{3}{c|}{ Number } & $\%$ \\
\cline { 2 - 8 } & 487 & 8.8 & 69 & 8.8 & 418 & 8.8 \\
\hline under 30 & 782 & 14.1 & 86 & 10.9 & 696 & 14.6 \\
\hline $30-39$ & 1084 & 19.5 & 142 & 18.1 & 942 & 19.7 \\
\hline $40-49$ & 1472 & 26.5 & 220 & 28 & 1252 & 26.2 \\
\hline $50-59$ & 1096 & 19.7 & 172 & 21.9 & 924 & 19.4 \\
\hline $60-69$ & 638 & 11.5 & 97 & 12.3 & 541 & 11.3 \\
\hline $70+$ & 5559 & 100 & 786 & 100 & 4773 & 100 \\
\hline Total & & & & & \multicolumn{2}{c|}{ men } \\
\hline
\end{tabular}




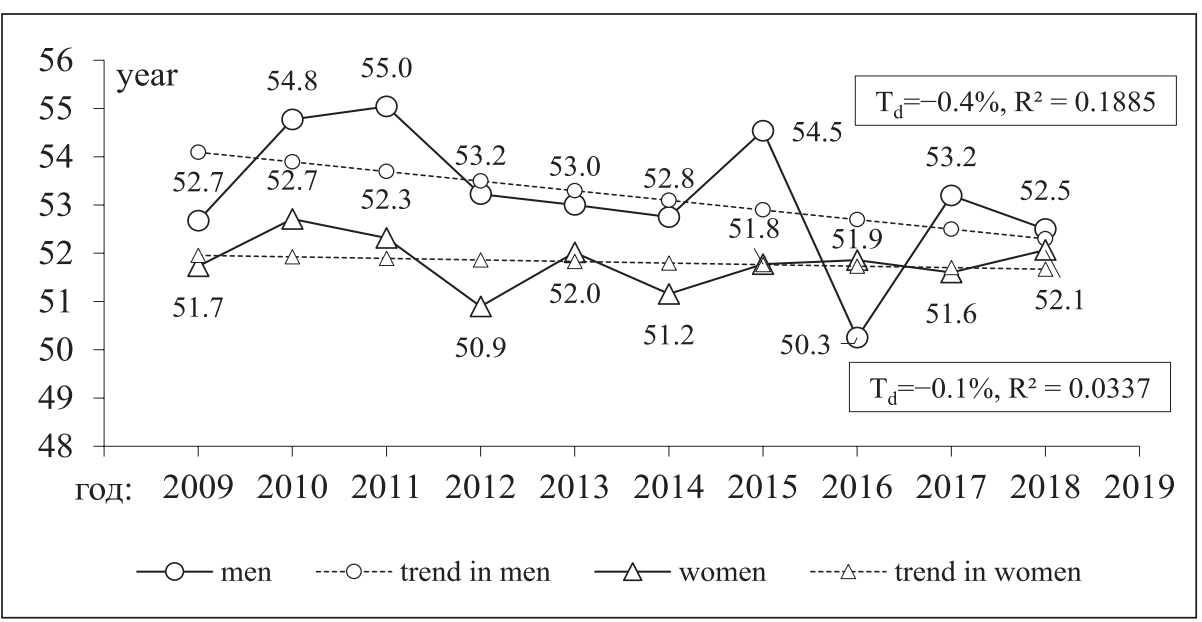

Figure 2 - Trends in the average age of men and women with TC in Kazakhstan, 2009-2018 crease in 60-69 years $(\mathrm{Td}=-0.7 \%)$, and to increase in other ages, and in women, the increase was noted in all age groups. At the same time, the most pronounced rates of morbidity increase were found in men aged $40-49$ years $(\mathrm{Tg}=+8.9 \%)$ and in women aged 30-39 years $(\mathrm{Tg}=+10.2 \%)$ (table 2$)$.

The cumulative risk of developing thyroid cancer in women was $0.51 \pm 0.04 \% \quad(95 \% \quad \mathrm{CI}=0.44$ $0.59 \%)$, and its dynamic tended to increase from $0.38 \%$ in 2009 to $0.63 \%$ in 2018 , while the average annual rate of return of the equalized cumulative risk indicator was $\mathrm{Tg}=+5.8 \%$ (figure 5 ).

In men, the cumulative risk of getting TC was statistically significantly lower $(p=0.02)$ than in women $-0.11 \pm 0.01 \%(95 \%$ $\mathrm{CI}=0.10-0.12 \%$ ), and the trends of the equalized indicators tended to increase, and the average annual rate of growth was $\mathrm{Td}=+3.0 \%$ (figure 5 ). and in dynamics it tended to increase from $51.7 \pm 0.8$ years (2009) to $52.1 \pm 0.6$ years in 2018 (figure 2), and when this indicator was equalized, it had an undetected downward trend, and the average annual rate of loss was $\mathrm{Td}=-0.1 \%$.

The average age of men was greater than in women it was $53.2 \pm 0.5$ years $(95 \% \mathrm{CI}=52.3-54.1$ years). Analyzing the average age of patients with TC, the dynamics revealed a tendency to a slight decrease $(\mathrm{Td}=-0.4 \%$ ) (figure 2$)$.

The average annual crude rate of $\mathrm{TC}$ in men was $0.95 \pm 0.06 \%$ (95\% CI=0,84-1,06\%ooo). In dynamics, the illness tended to increase from $0.74 \pm 0.10 \%$ (2000 to $1.09 \pm 0.11 \%$ oovo $\quad(2018) \quad(\mathrm{t}=2.35$; $\mathrm{p}=0.02$ ), and the rate of profit when equalized was $\mathrm{Tg}=+5.0 \%$ (figure 3 ).

The crude incidence of women TC in dynamics also increased from $3.84 \pm 0.22 \%$ (2009) to $6.52 \pm 0.26 \%$ in $2018 \quad(t=7.87$; $\mathrm{p}=0.000$ ), and the rate of profit when equalized was $\mathrm{Td}=+7.8 \%$ (figure 3), and the average annual crude rate was $5.37 \pm 0.42 \%$ ooo $(95 \%$ $\mathrm{CI}=4.55-6.18 \% 000)$.

The average annual age-standardized incidence rate of women's TC in the whole republic was $5.11 \pm 0.37 \% \quad(95 \% \quad \mathrm{CI}=4.38-5$ $85 \%$ ooo) higher than the same indicator in men- $1.08 \pm 0.05 \%$ \%oo $(95 \%$ $\mathrm{CI}=0.98-1,19 \%$ ooo $)$ (figure 4).

Age-specific incidence rate of TC had a unimodal increase with a peak in 60-69 years, both in men- $4.21 \pm 0.20 \% 000$, and in women-15.37 $\pm 1.21 \%$ ooo (table 2).

Trends in age-specific incidence rate of $\mathrm{TC}$ in men tended to de-

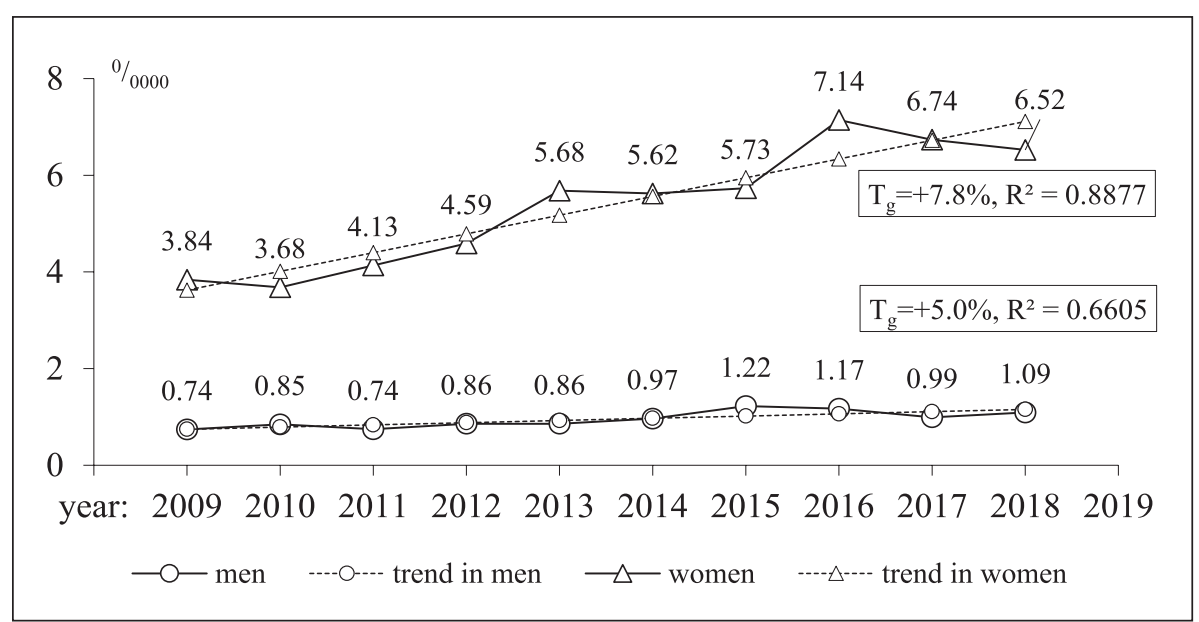

Figure 3 - Dynamics of crude incidence rate of thyroid cancer in men and women in Kazakhstan, 2009-2018

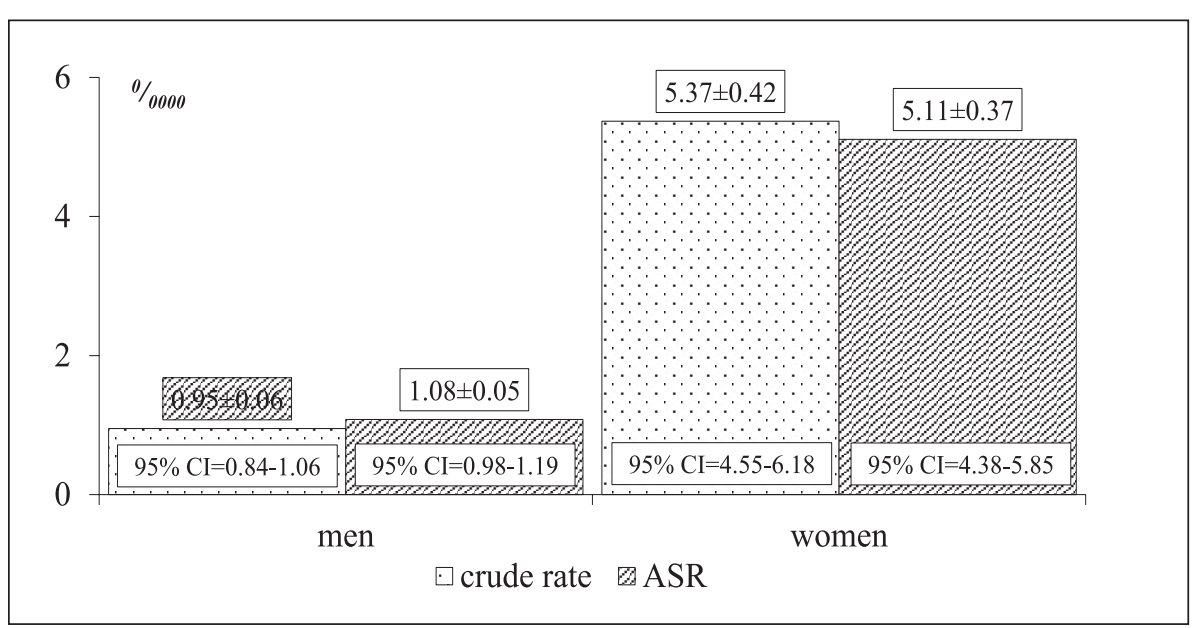

Figure 4 - Thyroid cancer incidence in men and women in Kazakhstan, 2009-2018 
Table 2 - Age-specific incidence rate of thyroid cancer in men and women in Kazakhstan, 2009-2018

\begin{tabular}{|c|c|c|c|c|c|c|}
\hline \multirow{2}{*}{ Age } & \multicolumn{5}{|c|}{ Men } & \multicolumn{3}{c|}{ Women } \\
\cline { 2 - 7 } & $\mathrm{P} \pm \mathrm{m}$ & $95 \% \mathrm{Cl}$ & $\mathrm{T}, \%(\mathrm{R} 2)$ & $\mathrm{P} \pm \mathrm{m}$ & $95 \% \mathrm{Cl}$ & $\mathrm{T}, \%(\mathrm{R} 2)$ \\
\hline$<30$ & $0.15 \pm$ & $0.12-0.19$ & $+5.80(0.2222)$ & $0.96 \pm$ & $0.78-1.15$ & $+6.06(0.3611)$ \\
\hline $30-39$ & $0.69 \pm$ & $0.56-0.82$ & $+3.80(0.1468)$ & $5.34 \pm$ & $4.33-6.35$ & $+10.23(0.918)$ \\
\hline $40-49$ & $1.36 \pm$ & $1.08-1.64$ & $+8.87(0.6122)$ & $8.33 \pm$ & $6.84-9.81$ & $+8.88(0.8123)$ \\
\hline $50-59$ & $2.60 \pm$ & $2.10-3.11$ & $+5.45(0.2801)$ & $12.53 \pm$ & $11.12-13.94$ & $+4.20(0.509)$ \\
\hline $60-69$ & $4.21 \pm$ & $3.82-4.59$ & - & $15.37 \pm$ & $13.00-17.73$ & $+7.69(0.8436)$ \\
\hline$\geqslant 70$ & $3.72 \pm$ & $2.90-4.53$ & $+2.25(0.0398)$ & $10.43 \pm$ & $8.87-11.99$ & $+5.65(0.5062)$ \\
\hline
\end{tabular}

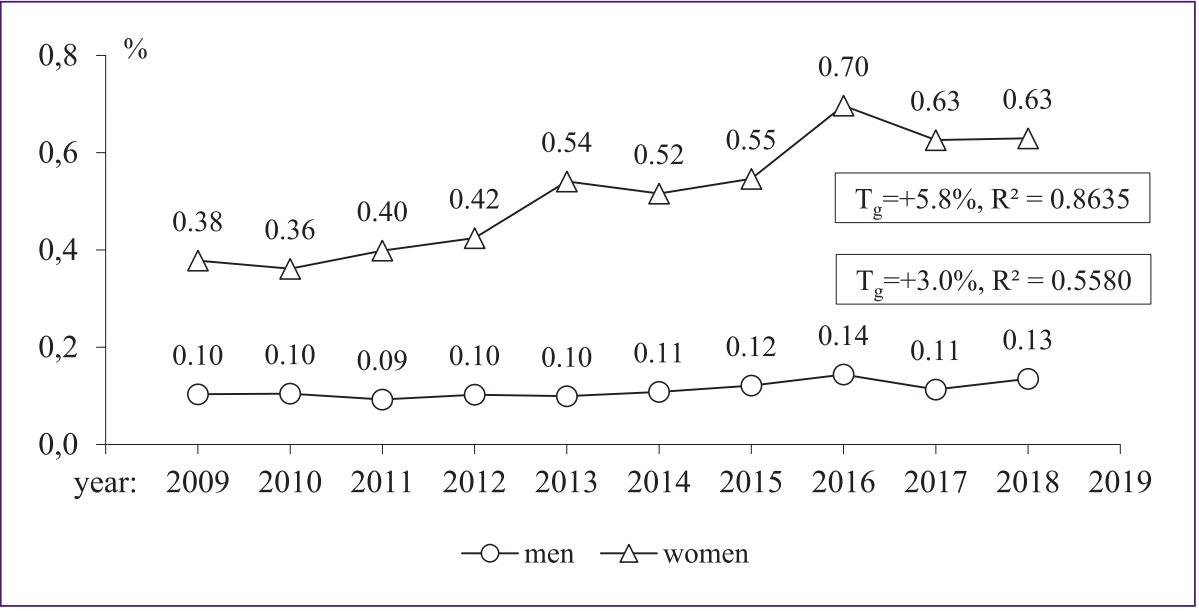

Figure 3 - Dynamics of crude incidence rate of thyroid cancer in men and women in Kazakhstan, 2009-2018

The epidemiological features of the incidence of TC have been established, which gives strong recommendation in organization of anti-cancer arrangements also in further deeper and targeted studies of the incidence of TC.

\section{CONCLUSIONS}

1. The average age of patients with $\mathrm{TC}$ in women $(51.8$ years) was significantly lower $(t=7.87 ; \mathrm{p}=0.000)$ than in men (53.2 years). Trend analysis of the average age indicates a decrease, and the value of the credible approximation doesn't have much difference between women and men (R2 $=0.0337$ women and R2 $=0.0337$ men, respectively).

2. The crude incidence of TC in women $(5,37 \%$ ooo) was higher $(p=0.000)$ than in men $(0.95 \%$ ooo $)$. In the dynamics, the indicators tended to increase, and the accuracy of the approximation was significantly higher in women $(\mathrm{R} 2=0.8877)$ than in men $(\mathrm{R} 2=0.6605)$.

3. The average annual age-standardized incidence rate in women $(5,11 \%$ ooo $)$ whereas in men $(1,08 \%$ ooo $)$. Also, there is no statistically meaningful difference in gross of men and women $(\mathrm{p}>0.05)$.

\section{REFERENCES}

1 Ferlay J, Ervik M, Lam F, Colombet M, et al. (2018). Global Cancer Observatory: Cancer Today. Lyon, France: International Agency for Research on Cancer. Available from: https:/gco.iarc.fr/ today, accessed december 2, 2020
4. Age specific incidence rate in men and women had a peak in 60-69 years: $4.21 \%$ ooo and $15.37 \% 000$ respectively.

5. Trends in age-specific incidence rates increased in almost all ages in both sexes, exception of 60-69 years. At the same time, the accuracy of the approximation was expressed in men aged 40-49 years $(\mathrm{R} 2=0.6122)$ and in women aged 30-39 years $(\mathrm{R} 2=0.9180)$, $40-49$ years $(\mathrm{R} 2=0.8123)$ and 60 69 years $(\mathrm{R} 2=0.8436)$

\section{Research transparency}

Research did not have a sponsorship. The authors are absolutely responsible for presenting the release script for publication.

Declaration about financial and other relations

The authors did not get the honorary for the article.

Authors' contribution

Yerlankyzy Moldir - data summary, primary processing of the material, writing the text of the article.

Turebaev Dulat - writing the text of the article (introduction, conclusions).

Sakhanov Sauirbay - writing the text of the article (results).

Bilyalova Zarina - statistical processing of the material, writing the text of the article (material and methods, conclusion).

Kulmirzayeva Dariyana - writing the text of the article, editing.

Urazova Saltanat - processing of the material, approval of the final version of the article, editing.

Amanshayeva Akmaral - writing the text of the article (results), editing.

Igissinov Nurbek - concept and design of the study, approval of the final version of the article.

Conflict of interest

The authors declare no conflict of interest.

\section{СПИСОК ЛИТЕРАТУРЫ}

1 Ferlay J., Ervik M., Lam F., Colombet M. et al. (2018). Global Cancer Observatory: Cancer Today. Lyon, France: International Agency for Research on Cancer. https://gco.iarc.fr/today, accessed december 2, 2020 
2 Bray F, Ferlay J, Soerjomataram I, et al. Global cancer statistics 2018: GLOBOCAN estimates of incidence and mortality worldwide for 36 cancers in 185 countries. CA Cancer J Clin. 2018 Nov;68(6):394-424. doi: 10.3322/caac. 21492

3 Ferlay J, Colombet M, Soerjomataram I, et al. Estimating the global cancer incidence and mortality in 2018: GLOBOCAN sources and methods. Int $J$ Cancer. 2019 Apr 15;144(8):941-1953. doi: $10.1002 / \mathrm{ijc} .31937$

4 Vaccarella S, Franceschi S, Bray F, et al. Worldwide thyroid-cancer epidemic? N Engl J Med. 2016;375(7):614-617. doi:10.1056/NEJMp1604412.

5 Kitahara CM, Sosa JA. The changing incidence of thyroid cancer. Nat Rev Endocrinol. 2016;12(11):646-653. doi: 10.1038/nrendo. 2016.110

6 Fraser S, Zaidi N, Norlén O, et al. Incidence and Risk Factors for Occult Level 3 Lymph Node Metastases in Papillary Thyroid Cancer. Ann Surg Oncol. 2016 Oct; 23(11):3587-3592. doi: 10.1245/ s10434-016-5254-8

7 Igissinov N, Kozhakhmetov S, Zhantubetova M, et al. Thyroid Cancer in Kazakhstan: Component Analysis of Incidence Dynamics. Asian Pac J Cancer Prev. 2019 Sep 1;20(9):2875-2880. doi: 10.31557/ APJCP.2019.20.9.2875

8 Pellegriti G, Frasca F, Regalbuto C, et al. Worldwide increasing incidence of thyroid cancer: update on epidemiology and risk factors. J Cancer Epidemiol. 2013;2013:965212. doi: 10.1155/2013/965212

9 Rumyantseva UV, Rumyantsev PO, Ilyin AA. Clinical and genetic aspects of diagnosis and treatment of hereditary forms of medullary thyroid cancer. Problemy endokrinologii $=$ Problems of Endocrinology. 2006;5(2):21-27. (In Russ.)

10 Cancer epidemiology: principles and methods/ Isabel dos Santos Silva. Lion, France: IARC, 1999

11 Primenenie metodov statisticheskogo analiza dlya izucheniya obshestvennogo zdorovya I zdrovoohraneniya [Application of statistical analysis methods for the study of public health and public health]. M: GEOTAR-MED; 2011:256

12 Toshiro Tango. Statistical Methods for Disease Clustering. Springer Science+Business Media, LLC; 2010:247

13 Merkov AM, Polyakov LE. Sanitarnaya statistika [Sanitary statistics]. Leningrad: Medicine; 1974:384

14 Omar B, Ahmad, Cynthia Boschi-Pinto, Alan D Lopez, et al. Age standardization of rates: a new who standard. GPE Discussion Paper Series: No.31 EIP/GPE/EBD World Health Organization 2001. Available from: http://www.who.int/healthinfo/paper31.pdf. (accessed November 10, 2020)

15 Recommendations of the National Cancer Institute (USA) on the use of the World Standard (WHO 2000-2025). Available from: http://seer.cancer.gov/stdpopulations/world.who.html (accessed November 10,2020$)$
2 Bray F., Ferlay J., Soerjomataram I. et al. Global cancer statistics 2018: GLOBOCAN estimates of incidence and mortality worldwide for 36 cancers in 185 countries // CA Cancer J Clin. 2018 Nov;68(6):394-424. doi: 10.3322/caac.21492

3 Ferlay J., Colombet M., Soerjomataram I. et al. Estimating the global cancer incidence and mortality in 2018: GLOBOCAN sources and methods // Int J Cancer. 2019 Apr 15;144(8):941-1953. doi: $10.1002 / \mathrm{ijc} .31937$

4 Vaccarella S., Franceschi S., Bray F. et al. Worldwide thyroidcancer epidemic? // N Engl J Med. 2016;375(7):614-617. doi:10.1056/ NEJMp1604412

5 Kitahara C.M., Sosa J.A. The changing incidence of thyroid cancer // Nat Rev Endocrinol. 2016;12(11):646-653. doi: 10.1038/ nrendo. 2016.110

6 Fraser S., Zaidi N., Norlén O. et al. Incidence and Risk Factors for Occult Level 3 Lymph Node Metastases in Papillary Thyroid Cance // Ann Surg Oncol. 2016 Oct; 23(11):3587-3592. doi: 10.1245/ s10434-016-5254-8

7 Igissinov N., Kozhakhmetov S., Zhantubetova M. et al. Thyroid Cancer in Kazakhstan: Component Analysis of Incidence Dynamic // Asian Pac J Cancer Prev. 2019 Sep 1;20(9):2875-2880. doi: 10.31557/APJCP.2019.20.9.2875

8 Pellegriti G., Frasca F., Regalbuto C. et al. Worldwide increasing incidence of thyroid cancer: update on epidemiology and risk factors // J Cancer Epidemiol. 2013;2013:965212. doi: 10.1155/2013/965212

9 Румянцева У.В., Ильин А.А., Румянцев П.О. Клинико-генетические аспекты диагностики и лечения наследственных форм медуллярного рака щитовидной железы // Проблемы эндокринологии. 2006;5(2):21-27

10 Cancer epidemiology: principles and methods/ Isabel dos Santos Silva. Lion, France: IARC, 1999

11 Применение методов статистического анализа для изучения общественного здоровья и здравоохранения. - М: ГЭОТАР-Медиа, 2011.- 256 с.

12 Toshiro Tango. Statistical Methods for Disease Clustering. Springer Science+Business Media, LLC; 2010:247

13 Мерков А.М., Поляков Л.Е. Санитарная статистика. Л., 1974. -384 c.

14 Omar B, Ahmad, Cynthia Boschi-Pinto, Alan D Lopez, et al. Age standardization of rates: a new who standard. GPE Discussion Paper Series: No.31 EIP/GPE/EBD World Health Organization 2001. http://www.who.int/healthinfo/paper31.pdf. (accessed November 10, 2020)

15 Recommendations of the National Cancer Institute (USA) on the use of the World Standard (WHO 2000-2025). http://seer.cancer. gov/stdpopulations/world.who.html (accessed November 10, 2020) 